\title{
Vulnerabilities and clinical manifestations in scorpion envenomations in Santarém, Pará, Brazil: a qualitative study*
}

\author{
Vulnerabilidades e manifestações clínicas em envenenamentos por \\ escorpiões em Santarém, Pará, Brasil: estudo qualitativo \\ Vulnerabilidades y manifestaciones clínicas en envenenamiento de \\ escorpiones en Santarém, Pará, Brasil: estudio cualitativo
}

How to cite this article:

Torrez PPQ, Bertolozzi MR, França FOS. Vulnerabilities and clinical manifestations in scorpion envenomations in Santarém, Pará, Brazil: a qualitative study. Rev Esc Enferm USP. 2020;54:e03579. doi: https://doi.org/10.1590/S1980-220X2018050403579

Pasesa Pascuala Quispe Torrez ${ }^{1,3}$

Maria Rita Bertolozzi²

Francisco Oscar de Siqueira França ${ }^{3}$

* Extracted from the thesis: "Estudo clínicoepidemiológico, laboratorial e de vulnerabilidade dos acidentes escorpiônicos atendidos no Hospital Municipal de Santarém - Pará”, Faculdade de Medicina da Universidade de São Paulo, 2016.

${ }^{1}$ Centro Avançado Avançado de Medicina Tropical, Santarém, PA, Brazil

${ }^{2}$ Universidade de São Paulo, Escola de Enfermagem, Departamento de Enfermagem em Saúde Coletiva, São Paulo, SP, Brazil.

${ }^{3}$ Universidade de São Paulo, Faculdade de Medicina, Departamento de Doenças Infecciosas e Parasitárias, São Paulo, SP, Brazil

\section{ABSTRACT}

Objective: To describe elements of vulnerabilities and clinical manifestations of the victims of scorpionism in Santarem-Pará. Method: Quantitative and qualitative study with a theoretical framework of Twenty-eight patients stung by scorpions were interviewed by applying a semi-structured instrument. Data were analyzed according to the technique of discourse analysis. Results: Seventeen patients $(60.7 \%)$ were male and eight $(28.6 \%)$ were illiterate. Twenty-two $(78.5 \%)$ patients were small farmers. This study revealed that these patients had an important individual, social and programmatic vulnerability. Interviews revealed limited knowledge about prevention and first aid after the envenomation. Programmatic vulnerability is highlighted because there is difficulty in accessing health services due to the great geographical extension of the Amazon region and also a lack of experience of the health care workers in caring for scorpion sting victims. Conclusion: This research accurately reveals previously described neuromuscular and sensory nervous system disorders in these victims of scorpionism. As far as we know, this is the first study that addresses the vulnerability of scorpionism using qualitative methodology.

\section{DESCRIPTORS}

Scorpion Stings; Health Vulnerability; Public Health Nursing; Qualitative Research. 


\section{INTRODUCTION}

Scorpionism is a health problem in Brazil and other regions of the world. There are approximately 1,800 species of scorpions worldwide. At least 34 of these are considered medically important. The species responsible for envenomations in South America belongs to the genus Tityus ${ }^{(1-3)}$. Globally, there are probably more than 1,200,000 scorpion stings and recent speculation suggests approximately 3,250 deaths per year. The annual incidence is 26.3 envenomations per 100,000 inhabitants and the mortality rate is $0.2 \%{ }^{(2)}$. It has been a notifiable disease in Brazil since 1988. In 2017, 126,000 envenomations and 184 deaths were reported ${ }^{(4)}$.

More than $80 \%$ of scorpion envenomations are classified as mild. The severity of the systemic effects depends on venom composition and patient clinical condition. Children under ten and the elderly over 75 years old are generally more seriously affected. The vast majority of deaths have occurred in these ages ${ }^{(2)}$.

Scorpion venoms have at least one hundred different components, with activities in many ion channels. The most medically important scorpion venom toxins affect the $\mathrm{Na}^{+}$ and $\mathrm{K}^{+}$channels and are also active on the chloride and calcium channels which are present in all cell membranes ${ }^{(5-10)}$. This usually leads to membrane depolarization of muscles and nerves (sensory and autonomic nervous system) causing a massive release of neurotransmitters (epinephrine and acetylcholine) $)^{(5,9)}$.

Mild envenomations are characterized by immediate local pain. Systemic manifestations, when present, can occur within minutes of the envenoming. Moderate cases may present nausea, vomiting, abdominal pain, cramps, diarrhea, fever, sweating, and diaphoresis. Severe envenomations usually evolve with symptoms compatible to acute congestive heart failure due to increased vascular resistance and acute pulmonary edema that may manifest as tachypnea, dyspnea, hypoxia, hypotension, cardiac arrhythmia, bradycardia, and shock. Less frequently, nervous and/or muscular system such as psychomotor agitation, somnolence, tremors, mental confusion, seizures, and muscle contractions have been reported in some regions of the world ${ }^{(11-16)}$. Antiarachnid/ scorpion or scorpion antivenom should be administered as early as possible in patients with systemic alterations with the dosage in according to the severity. Autonomic nervous system (ANS) manifestations observed in severe scorpion envenoming in some parts of the world are much less frequent in patients from the Santarem region of Brazil. The predominant manifestations in this region relate to acute cerebellar dysfunction and they present as electric shock sensations which can last hours. The vast majority of patients present a clinical manifestations compatible with acute cerebellar dysfunction which starts minutes afer envenoming and can last for up to two days ${ }^{(17-19)}$.

Previous publications have shown that the clinical manifestations observed in the Santarém region is completely different to any other scorpion envenoming in the world $^{(1,12,20)}$. Given the novelty and peculiarity of clinical features currently and exclusively attributed to Tityus obscurus in this region of Pará State (Brazil), elements of vulnerability and aspects related to clinical symptomatology were evaluated by quantitative and qualitative approach $^{(17-19)}$.

\section{METHOD}

\section{StUdy DESIGN}

This is a hermeneutic, qualitative, observational, descriptive and prospective study. It is based on the theoretical framework of vulnerability, aiming to understand that a scorpion sting is not limited to an individual's exposure to the animal, but results from situations and contexts that involve the person's life, work activity, access to health services, knowledge about the envenomations and other factors that will determine envenomation occurrence, progression, and severity.

The conceptual basis allowed us to process the reading and interpretation of these accidents from a vulnerability viewpoint to broaden our understanding of these envenomations and support proposals to better meet patient needs, program actions, and health policies.

The concept of vulnerability, according to Ayres et $\mathrm{al}^{(21)}$, integrates the following dimensions: individual, social and programmatic. Individual Vulnerability refers to the degree and quality of information that individuals have about health problems, and how they elaborate and apply this information in practice; Social Vulnerability assess information acquisition, access to the media, the availability of cognitive and material resources, and the power to participate in policy decisions and institutions; and Programmatic Vulnerability refers to the program evaluation and how it responds to the health problem control; besides it refers to the degree and quality of an institution's commitment, resources, management and monitoring of programs at different levels of ${ }^{(21)}$.

\section{SCENARIO}

Santarém Municipal Hospital (MHS) is the main medical center in the northwest region of Pará State. This is a frontline medical centre for almost 1,200,000 people that live in Santarem and nearby. This town, the second most important in Pará, is located on the bank of the Tapajos River with an estimated population of $302,667^{(22)}$. The city has extensive deforestation due to soybean plantations.

\section{Data collection}

Patients admitted and hospitalized at MHS, from February 2013 to January 2014, were interviewed. Twentyeight patients treated for scorpion envenoming at the Hospital during this time were included in the study.

Interviews were guided by an instrument consisted of two parts: Part One was structured in closed questions to obtain social, demographic, and epidemiological data; Part Two: semi-structured to understand elements of vulnerability and symptomathology by allowing patients free expression in answering the following questions: "Tell me how the accident occurred?"; "What should be done after a scorpion sting?"; "Why did you seek help at the hospital?"; "What is 
the treatment for a scorpion sting?"; "Do you know how to identify a venomous scorpion?"; and "Do you have any way to avoid being stung by scorpions"?

All interviews were recorded at the hospital or at patients'homes by the researcher who had no prior relationship with patients thus ensuring their freedom of expression. Patient privacy was always a foremost concern.

\section{DATA ANALYSIS AND PROCESSING}

Data related to the semi-structured part of the study were fully transcribed and analyzed according to the technique of discourse analysis proposed by Fiorin and Savioli and adapted by Car and Bertolozzi ${ }^{(23)}$ based on the Theory of Greimás: the Construction of Meaning Making, whose themes and figures are extracted from testimonials. Systematic reading of the statements was performed and then concepts and thematic categories were identified ${ }^{(23-24)}$. To ensure the anonymity of the participants of this research, each interview was coded.

Analysis was performed by one of the researchers with expertise in qualitative research. Analysis validation was performed by the interviewer and results discussed together with the other authors.

The analysis generated analytical categories - perception about: the situation in which the accident occurred; the animal; clinical manifestations; procedures after the accident; treatment in the health service; and prevention actions. We complied with qualitative research review guidelines - RATS ${ }^{(25)}$.

\section{ETHICAL ASPECTS}

The study was approved by University of Sao Paulo Research Ethics Committee (CAPPesq number: 1128/07 and 0153/07). All patients gave their free and informed consent.

All precautions related to interview confidentiality were adopted.

\section{RESULTS}

According to Table 1, 28 patients (17 males: 60.7\%) were included; ages ranged from 1 to 70 years; the highest accident rate was in the $21-30$ years age group (32.1\%); the prevailing schooling range was between 1 and 3 years completed (46.4\%); eight patients were illiterate (28.6\%). The majority of envenomations occurred while at work 26 (92.9\%). The most important occupation was smallholdings farmer 22 (78.5\%), the others worked in wood extraction. The majorities of patients had no occupational qualification (24: 85.7\%) and they were not registered in the National Employment Record Booklet; 22 (78.6\%) patients worked 40 hours or more per week (Table 1 ).

Over $60 \%$ of those interviewed lived with at least 7 people and $35 \%$ in wooden houses with palm leaf rooves. The majority of patients were owner (78.6\%), housing conditions were very poor, none lived in residences with a sewage system; $57 \%$ had running water, and only $46 \%$ had regular garbage collections. Paradoxically, two-thirds (60.7\%) of the population reported that their living resources were sufficient and that they depended on public transport (82.1\%) (Table 2).

Table 1 - Distribution of patient's victims of scorpions stings according to epidemiological variables - MHS, Santarem, Pará, Brazil, 2013-2014.

\begin{tabular}{lccc}
\hline Indicator & Variable & $\mathbf{N}=\mathbf{2 8}$ & $\%$ \\
\hline \multirow{2}{*}{ Gender } & Male & 17 & 60.7 \\
& Female & 11 & 39.3 \\
\hline \multirow{3}{*}{ Age (years) } & $1-10$ & 2 & 7.1 \\
& $11-20$ & 2 & 7.1 \\
& $21-30$ & 9 & 32.1 \\
& $31-40$ & 4 & 14.3 \\
& $41-50$ & 5 & 17.9 \\
Schooling * & $51-60$ & 2 & 7.1 \\
& $61-70$ & 4 & 14.3 \\
\hline \multirow{3}{*}{ Marital status } & 0 & 8 & 28.6 \\
& 1 to 3 & 13 & 46.4 \\
& 4 to 7 & 6 & 21.4 \\
& +7 & 17 & 3.6 \\
\hline *Completed years of study & Married & 8 & 60.7 \\
& Single & 1 & 28.6 \\
& Divorced & 2 & 7.1 \\
\hline
\end{tabular}

*Completed years of study

Table 2 - Distribution of patient's victims of scorpions stings according to resources for living - MHS, Santarem, Pará, Brazil, 2013-2014.

\begin{tabular}{lcrr}
\hline Indicator & Variable & $\mathrm{N}=\mathbf{2 8}$ & \multicolumn{1}{c}{$\%$} \\
\hline \multirow{2}{*}{ Who they live with } & Alone & 3 & 10.7 \\
& With Family & 25 & 89.3 \\
\hline People who live & $1-3$ & 2 & 7.1 \\
in the home & $4-6$ & 9 & 32.1 \\
& $7-9$ & 17 & 60.7 \\
\hline \multirow{2}{*}{ Ownership of property } & Owner & 22 & 78.6 \\
& Borrowed & 4 & 14.3 \\
\hline Material used for & Rented & 2 & 7.1 \\
building the house & Masonry & 18 & 64.3 \\
& Wood & 10 & 35.7 \\
\hline \multirow{2}{*}{ humber of rooms in the } & 1 - 3 & 5 & 17.9 \\
& 4 - 6 & 21 & 75.0 \\
& 7 & 2 & 7.1 \\
\hline House & Lack of piped water & 16 & 57 \\
& Lack of sewage & 28 & 100 \\
\hline Sufficiency of resources & Lack of asphalt & 20 & 71.4 \\
for living & Lack of garbage collection & 13 & 46.4 \\
\hline Transportation Used & Yes & 17 & 60.7 \\
\hline community groups & No & 11 & 39.3 \\
\hline
\end{tabular}

\section{THE SITUATION IN WHICH THE ENVENOMATION OCCURRED}

Patients were stung at work (...) picking up wood (P8, P13, $\mathrm{P} 20), \ldots$ while harvested açaí palm fruit (P5),... when pulling a stick in (P26), ... burning garbage or when cleaning the house or getting dressed (P10, P11).

\section{ABOUT THE ANIMAL}

The patients interviewed identified the animal that caused the envenomation by the popular name of "lacrau" (P1, P2, P3, P4, P9, P10, P19), as a "big black" venomous animal (P1, P2, P3, P5, P8, P19, P20). 
CONCERNING THE INITIAL MANIFESTATIONS OF THE ENVENOMATION

(...) weakness and difficulty in feeling objects while manipulating them (P8).

The first symptom after the envenomation was intense pain in the foot that ... spread to my leg ... then I felt a shock in my hand ... I could not sit or sleep (P16).

(...) I started to feel numbness in my arm and legs ... and three hours after the envenomation, I could not feel them ... just touching me I had a feeling of shock, ... when walking I felt my legs were heary (P20).

(...) A terrible sensation as an electric shock... my hand felt very heavy ... it also became swollen ... (P24).

A patient also reported a (...) taste of mud in the mouth (P17).

\section{SPEECH-RELATED DISORDERS AND RELATED MANIFESTATIONS}

(...) Felt my tongue curled and my throat closed (P3). Difficulty to talk (P3).

I began to drool and my tongue was tied, I did not speak correctly (P5).

My throat swelled (P23).

(...) my tongue rolled, I could not speak and had a continuous shock sensation... (P18, P19).

After the envenomation ... I began to drool (P5), ... the tongue got stuck, did not speak right ... (P3, P9, P22, P23, P25).

I thought I would be paralyzed ... my speech cut all the time, I felt my tongue heavy, wanting to curl ... but I did not lose all speech, it was only scrambled, feeling a dry throat ... (P23).

\section{AtAXIA AND OTHER MANIFESTATIONS OF THE CENTRAL NERVOUS SYSTEM}

It was difficult to walk (P3, P7, P9, P10, P11, P13, P22, P24). I had the feeling that I would fall (P1, P3).

I had no motor coordination to walk... after the serumtherapy ... it gradually improved...but I needed help to get out of bed and to go to the bathroom... for everything ... I got better in three days $(\mathrm{P} 1)$.

\section{ReNAL MANIFESTATIONS}

I had a sensation of shock [electrical] and later ... urine with blood (P22).

\section{CONCERNING THE PROCEDURES AFTER THE ENVENOMATION}

(...) garlic, alcohol, and lukewarm water (P5).

After the bite, we put a black stone. ...There are people who tie the animal to the sting site; they say it is to stop the venom spreading through the body (P22, $\mathrm{P} 28)$.

Others applyed onion and drank cow milk (P19).

Some patients applied "tapir fat" [Tapir, a ground-dwelling and aquatic mammal], to the sting site (P22, P28).
(...) apply egg or tobacco (P16, P28); constricted the limb with straw; take bitter coffee; (...) or cachaça, as in the past when there was no serum ... I got better $(\mathrm{P} 1, \mathrm{P} 2, \mathrm{P} 3)$.

Preserving the scorpion in alcohol and drinking this liquid is an antidote against the scorpion sting; the local sucking ...reduces venom absorption (P26).

Many scorpion sting victims do not know what should be done after the accident (P1, P2, P5, P11, P16, P26, P27, P28).

\section{About hospital CARE}

There was no antivenom at the Hospital for treatment (P7) but patients reported that they were well treated by health professionals (P9, $\mathrm{P} 10)$.

\section{ConCERNING THE PREVENTION}

Patients believe that envenomations can be prevented by: cleaning dry leaves from the yard, removing garbage $(\mathrm{P} 1, \mathrm{P} 2$, P3, P19, P25, P28), not entering the forest and vacant lots (P2), avoid destroying the forest which can attract animals to urban homes (P3), and (...) If you sleep in the bush check your boots or shoes before putting them on the next day $(\mathrm{P} 4, \mathrm{P} 10, \mathrm{P} 13$, P16, P20, P21); wearing long boots and gloves up the arms (P14, P17, P26); shaking out clothes before getting dressed and avoiding dirt in corners of the house (P12).

\section{DISCUSSION}

The social context in the amazonic region are characterized by: growing social inequality, low human development index, low-income population, disorderly urban growth, land conflict, increase in deforestation (mainly caused by fire), difficulty in accessing health services in remote areas, reduced number of health professionals, limited resources, weak social control, poor access to health education and particularly to health policies, among others elements of vulnerability.

The study highlights the particular characteristics of scorpionism in Santarém and the most important aspects of vulnerability and symptomatology for these patients. Poor schooling and poor access to information may limit adequate post envenomation management and delay admission to the health service indirectly revealing the presence of individual and social vulnerability. Data that suggest important individual and social vulnerabilities may have influenced the occurrence of the envenomations, based in Table 1 and Table 2 .

Although these animals are extraordinarily adaptive with a wide natural distribution capacity, the envenomations in this study were predominantly from rural areas. Northern region alone accounts for about two thirds of all rural area envenomations in Brazil and some in peri-urban areas by scorpions. In contrast, scorpionism is predominantly an urban envenomation over the country as a whole $(61.6 \%)^{(1,26)}$. In this study scorpionism occurred, most of the time, when the patient was working, cutting wood or harvesting açai palm fruit.

Although the recognition of the animal is usual among the population, it is necessary to identify the species, since there are several genera of scorpions with wide distribution 
in the region, but apparently only the genus Tityus has medical importance. We should enphasied that the clinical manifestations observed in this study appear to be related only to Tityus obscurus.

Weakness (hypotonia) and difficulty in "feeling" objects while manipulating them are the consequence of abnormalities observed in tactile perception. Sensations of numbness and electric shock are related to proprioceptive function impairment as reported by patient P8. It is important to stress that these manifestations occurred simultaneously to many patients.

Soon after being stung, patients reported pain, which could be intense and spreading, commonly feeling numbness or local electrical shock that could become more generalized. Patients also complained of other local and regional manifestations that indicated muscle strength impairment. In fact, pain is the most frequent local manifestation; it is often intense and can last for several hours as scorpion toxins activate nociceptors, producing pain by dramatically slowing inactivation of sodium channels ${ }^{(27)}$. The "electric shock sensation" generally appears within 15 minutes of the sting and occurs in nearly all cases ${ }^{(17)}$. P17 revealed gustatory alteration compatible with impairment of the VII cranial pair. Taste disturbance (... the tongue tastes like mud) may be due to changes in tongue sensitivity.

Some interviewees reported to drool, difficulty swallowing, speaking and hypotonia (dragging legs). All these manifestations are compatible with motor coordination dysfunction, which is dependent on the cerebellum ${ }^{(17-19)}$.

Probably, the patient 22 witnessed dark colored urine which could correspond to myoglobinuria. Renal impairment is extremely rare in scorpionism; however, an earlier study described two cases in the Santarém region with renal injury presumably caused by T. obscurus ${ }^{(17)}$.

Many patients ingested or applied substances locally, only afterwards seeking medical attention because of no clinical improvement.

The Government's Health Department discourages any home treatments such as: drinking alcohol, blowing tobacco smoke on the site, or using a tourniquet, as they do not provide any benefits ${ }^{(28)}$. It recommends taking the victim to a medical reference unit as soon as possible ${ }^{(1)}$. However, such advice does not seem to be widely disseminated in the study region, which shows elements of individual and social vulnerability as well as a clear deficiency in the implementation of the National Program for the Control of Accidents by Venomous Animals.

Scorpionism interventions such as tourniquet, sucking the wound, local incision, and use of contaminated topical substances, although rare can lead to local complications; again, revealing individual, social, and programmatic vulnerability.

Patient could present a better prognosis if pre-hospital care (conduct soon after the envenomation) and adequate pre-hospital procedures are performed. It is essential that patients are quickly to the Health Service. Decentralization of specific antivenom distribution in the region and an increase of health professionals in difficult to access communities are essential for improving assistance in venomous animal accidents.

The Hospital was found to have no serum; in one case serum was only administered 17 hours after admission (P7) which indicates programmatic vulnerability. However, patients said they were well treated in the Hospital and that the doctor evaluated them regularly (P9, P10).

Using personal protection equipment such as closed footwear, long boots, leather gloves, especially when handling construction materials or transporting firewood, wood and stones, are effective measures to avoid scorpionism ${ }^{(1)}$.

These facts reveal that most of the patients were individually and socially vulnerable. The population should have access to information on how to correctly identify and avoid 'dangerous scorpions'.

We identified the following elements of individual and social vulnerability: socio-demographic characteristics, such as low levels of education (together with some illiteracy), low professional skills, poor housing conditions, and a lack of adequate information regarding the measures to be taken after a scorpion injury. These conditions could demonstrate inequality and social exclusion.

This study confirms previous publications that in the Santarém region occurs unique clinical manifestations of scorpionism. In summary reveals that these envenomations compromise acute cerebellar function as evidenced by ataxia, dysarthria, dysmetry; peripheral motor nervous system exemplified by fasciculations, myoclonus, hypertonia, spasms and even hypotonia. In relation to the Sensory Peripheral Nervous System, patients reported pain and abnormalities in tactile perception, numbness, and electric shocks in the body. Perhaps this venom concentrates its activities in other ion channel families $\left(\mathrm{Na}^{+}, \mathrm{K}^{+}\right)$found in cell membranes expressed in cerebellar neurons beyond autonomic nervous system ${ }^{(29-30)}$

These findings were only possible thanks to the qualitative approach that enabled the emergence of perceptions and representations about scorpionism ${ }^{(31)}$.

\section{CONCLUSION}

To the best of our knowledge this is the first qualitative study that identifies and evaluates clinical symptoms and vulnerabilities after scorpion stings. It describes with greater precision previously reported neuromuscular manifestations (mainly cerebellar) and reveals other abnormalities that have not previously been described as nervous system abnormalities: sensitivity, neuromuscular, cranial pair abnormalities such as gustatory and speech-related disorders, and renal irregularities in hospitalized scorpion sting patients from the Santarém region.

The qualitative approach decisively contributes to the detection of clinical manifestations and demonstrated that the population describes in its own way characteristics and aspects that are barely discernible in exclusively quantitative studies, such as paraesthesia epitomized by the "sensation of electric shock".

This study expressively revealed the individual, social, and programmatic vulnerabilities of this population. There is a need to improve the management of this injury through 
health professional training, including nurses, as well as improving access to the reference hospitals.

Programmatic vulnerability emerges when there is difficulty in accessing health services and a lack of knowledge among professionals in Basic Health Units and hospitals, probably due to limited access to continuing education. Eventually, there is a lack of antivenom at the only reference center in the area, reinforcing the need for the National Program for the Control of Accidents by Poisonous Animals to improve its public policies and actions.

\section{RESUMO}

Objetivo: Descrever elementos de vulnerabilidades e manifestações clínicas das vítimas de escorpionismo em Santarém-Pará. Método: Estudo quantitativo e qualitativo, com referencial teórico de 28 pacientes picados por escorpiões, foram entrevistados mediante aplicação de instrumento semiestruturado. Os dados foram analisados de acordo com a técnica de análise de discurso. Resultados: Dezessete pacientes $(60,7 \%)$ eram do sexo masculino e oito $(28,6 \%)$ eram analfabetos. Vinte e dois $(78,5 \%)$ pacientes eram pequenos agricultores. $\mathrm{O}$ estudo revelou que esses pacientes apresentavam uma importante vulnerabilidade individual, social e programática. As entrevistas revelaram conhecimento limitado sobre prevenção e primeiros socorros após o envenenamento. A vulnerabilidade programática é destacada porque há dificuldade no acesso aos serviços de saúde devido à grande extensão geográfica da região amazônica e também à falta de experiência dos profissionais de saúde no atendimento às vítimas de picadas de escorpião. Conclusão: Esta pesquisa revela com precisão os distúrbios neuromusculares e sensoriais do sistema nervoso descritos anteriormente nessas vítimas de escorpionismo. Até onde sabemos, este é o primeiro estudo que aborda a vulnerabilidade do escorpionismo usando metodologia qualitativa.

\section{DESCRITORES}

Picadas de Escorpião; Vulnerabilidade em Saúde; Enfermagem em Saúde Pública; Pesquisa Qualitativa.

\section{RESUMEN}

Objetivo: Describir los elementos de vulnerabilidades y manifestaciones clínicas de las víctimas del escorpionismo en Santarem-Pará. Método: Estudio cuantitativo y cualitativo, con marco teórico de veintiocho pacientes picados por escorpiones, que fueron entrevistados mediante la aplicación de un instrumento semiestructurado. Los datos fueron analizados de acuerdo con la técnica de análisis del discurso. Resultados: Diecisiete pacientes $(60.7 \%)$ eran hombres y ocho $(28.6 \%)$ eran analfabetos. Veintidós $(78,5 \%)$ pacientes eran pequeños agricultores. Este estudio reveló que estos pacientes tenían una importante vulnerabilidad individual, social y programática. Las entrevistas revelaron el reduzido conocimiento sobre la prevención y primeros auxilios después del envenenamiento. La vulnerabilidad programática se destaca porque hay dificultades para acceder a los servicios de salud debido a la gran extensión geográfica de la región amazónica y también la falta de experiencia de los trabajadores de salud en el cuidado de las víctimas de picaduras de escorpiones. Conclusión: Esta investigación eviencio con exactitud los trastornos neuromusculares y sensoriales del sistema nervioso descritos anteriormente en estas víctimas del escorpionismo. Hasta donde sabemos, este es el primer estudio que aborda la vulnerabilidad del escorpionismo utilizando la metodología cualitativa.

\section{DESCRIPTORES}

Picaduras de Escorpión; Vulnerabilidad en Salud; Enfermería en Salud Pública; Investigación Cualitativa.

\section{REFERENCES}

1. Brasil. Ministério da Saúde; Secretaria de Vigilância em Saúde, Departamento de Vigilância Epidemiológica. Manual de controle de escorpiões [Internet]. Brasília; 2009 [citado 2018 jul. 13]. Disponível em: http://vigilancia.saude.mg.gov.br/index.php/download/manualde-controle-de-de-escorpioes/

2. Chippaux JP, Goiffon M. Epidemiology of scorpionism: a global appraisal. Acta Trop. 2008;107(2):71-9.

3. De Roodt AR, Garcia SI, Salomóm OD, Lilian S, Dolab JA, Funes RF, et al. Epidemiological and clinical aspects of scorpionism by Tityus trivittatus in Argentina. Toxicon. 2003;41(8):971-7.

4. Brasil. Misistério da Saúde, Secretaria de Vigilância em Saúde, Sistema de Informação de Agravos de Notificação (SINAN). Registro de acidentes e óbitos por picada de escorpião [Internet]. 2018 [citado 2018 jul. 13]. Disponível: http://portalsinan.saude.gov.br/

5. Guerrero-Vargas AJ, Mourão CBF, Possani LD, Quinteiro-Hernández V, Schwaertz E. Identification and phylogenetic analysis of Tityus pachyurus and Tityus obscurus novel putative Na+-channel scorpion toxins. PloS One. 2012;7(2):e30478.

6. Prestipino G, Corzo G, Romeo S, Murgia AR, Zanardi I, Gurrola GB, et al. Scorpion toxins that block transient currents I (A) of rat cerebellum granular cells. Toxicol Lett. 2009;187(1):1-9.

7. Batista CV, Román-González SA, Salas-Castillo SP, Zamudio FZ, Gómez-Lagunas F, Possani LD. Proteomic analysis of the venom from the scorpion Tityus stigmurus: biochemical and physiological comparison with other Tityus species. Comp Biochem Physiol C Toxicol Pharmacol. 2007; 146(1-2):147-57.

8. Possani LD, Rodriguez de la Vega RC. Scorpion venom peptides. In: Kastin A, Kastin AJ, editors. Handbook of biologically active peptides. Amsterdam: Elsevier; 2006. p. 339-54.

9. Possani LD, Becerril B, Delepierre M Tytgat J. Scorpion toxin specific for Na+ - channels. Eur J Biochem. 1999;264(2):287-300.

10. Gordon D, Saravin P, Gurevitz M, Zinn-Justin S. Functional anatomy of scorpion toxins affecting sodium channels. J Toxicol Toxin Rev. 1998;17(2):131-59.

11. Cupo P. Clinical update on scorpion envenoming. Rev Soc Bras Med Trop. 2015;48(6):642-9.

12. Cupo P, Azevedo Marques MM, Hering SE. Escorpionismo. In: Cardoso JLC, França FOS, Malaque CMS, Haddad Junior V, editores. Animais peçonhentos no Brasil: biologia, clínica e terapêutica dos acidentes. 2a ed. São Paulo: Sarvier; 2009. p. 214-24.

13. Cupo P, Figueiredo AB, Filho AP, Pintya AO, Tavares Junior GA, Caligaris F, et al. Acute left ventricular dysfunction of severe scorpion envenomation is related to myocardial perfusion disturbance. Int J Cardiol. 2007;116(1):98-106. 
14. Cupo P, Jurca M, Azeedo-Marques MM, Oliveira JS, Hering SE. Severe scorpion envenomation in Brazil. Clinical, laboratory and anatomopathological aspects. Rev Inst Med Trop São Paulo. 1994;36(1):67-76.

15. Amaral CF, Rezende NA, Freire LM. Acute pulmonary edema after Tityus serrulatus scorpion sting in children. Am J Cardiol.1993;15;71(2):242-5.

16. Amaral CF, Lopes JA, Magalhães RA, Rezende NA. Electrocardiographic, enzymatic and echocardiograpic evidence of myocardial damage after Tityus serrulatus scorpion poisoning. Am J Cardiol. 1991;67(7):665-7.

17. Torrez PP, Quiroga MM, Abati PA, Mascheretti M, Costa WS, Campos LP, et al. Acute cerebellar dysfunction with neuromuscular manifestations after scorpionism presumably caused by Tityus obscurus in Santarém, Pará/Brazil.Toxicon. 2015;96:68-73.

18. Pardal PP, Ishikawa EA, Vieira JL, Coelho JS, Dórea RC, Abati PA, et al. Clinical aspects ofen venomation caused by Tityus obscurus (Gervais, 1843) in two distinct regions of Pará state, Brazilian Amazon basin: a prospective case series. J Venom AnimToxins Incl Trop Dis. 2014;20(1):3.

19. Pardal PPO, Castro LC, Jennings E, Pardal JSO, Monteiro MRCC. Aspectos epidemiológicos e clínicos do escorpionismo na região de Santarém, Estado do Pará, Brasil. Rev Soc Bras Med Trop. 2003;36(3):349-53.

20. Amaral CF, Dias M, Campolina D, Proietti FA, Rezende NA. Children with adrenergic manifestation sofen venomation after Tityus serrulatus scorpion sting are protected from early anaphylactic antivenom reactions. Toxicon. 1994;32(2):211-5.

21. Ayres JR, França JI, Calazans GJ, Salletti FH. Vulnerabilidade e Prevenção em tempos de AIDS. In: Barbosa MR, Parker R, editores. Sexualidade pelo avesso: direitos, identidades e poder. Rio de Janeiro: IMS/UERJ; 1999. p. 49-72.

22. Instituto Brasileiro de Geografia e Estatística. Censo demográfico 2010 [Internet]. Rio de Janeiro: IBGE; 2010 [citado 2018 jul. 13 ]. Disponível em: https://censo2010.ibge.gov.br/resultados.html

23. Car MR, Bertolozzi MR. O procedimento da análise de discurso. In: Associação Brasileira de Enfermagem. A Classificação Internacional das Práticas de Enfermagem em Saúde Coletiva - CIPESC. Brasília: ABEn; 1999. p. 348-55.

24. Fiorin JL, Savioli FP. Para entender o texto: leitura e redação. São Paulo: Ática; 1991.

25. Clark J. How to peer review a qualitative manuscript In: Godlee F, Jefferson T, organizadores. Peer review in health sciences. London: Elsevier; 2003.

26. Reckziegel GC, Pinto VL Jr. Scorpionism in Brazil in the years of 2000 to 2012. J Venom Animal Toxins Incl Trop Dis. $2014 ; 20: 46$.

27. Lewin GR. Evolution natural selection and pain meet at a sodium channel. Science. 2013; 342(6157):428-9.

28. Pinho FMO, Oliveira ES, Faleiros F. Acidente ofídico no estado de Goiás. Rev Assoc Med Bras. 2004;50(1):93-6.

29. Escalona MP, Possani LD. Scorpion beta-toxins and voltage-gated sodium channels: interactions and effects. Front Biosci (Landmark Ed). 2013;18:572-87.

30. Catterall WA, Cestèle S, Yarov-Yarovoy V, Yu FH, Konoki K, Scheuer T. Voltage-gated ion channels and gating modifier toxins. Toxicon. 2007; 49:124-41.

31. Minayo MCS. Sampling and saturation in qualitative research: consensuses and controversies. Rev Pesq Qual. 2017;5(7):1-12. 